\title{
Seroprevalence of Avian Influenza (subtype H9) in ducks at AI risk areas of Nepal
}

\author{
N. R. Pradhan ${ }^{1 *}$, S. Singh ${ }^{2}$ and M. P. Acharya ${ }^{3}$ \\ ${ }^{1}$ Directorate of Livestock Services Training and Extension, Lalitpur \\ ${ }^{2}$ Agriculture and Forestry University, Chitwan \\ ${ }^{3}$ National Cattle Research Program, Chitwan \\ *Corresponding author: navaratna91@gmail.com
}

\begin{abstract}
A study was conducted in duck population of Nepal from August-2013 to March-2014 as to find out the seroprevalence of Low pathogenic Avian Influenza (LPAI) subtype H9. Altogether 300 blood samples were taken from avian influenza risk areas of Nepal by using purposive sampling method and were analyzed in virology laboratory, Animal Health Research Division, NARC, Khumaltar. The serum samples were processed for Haemagglutination Inhibition (HI). Of the 300 serum samples, 16 samples showed HI positive (at $>3^{\text {rd }}$ well) at two-fold dilution revealing revealing $5 \%$ Seroprevalence of LPAI H9 and overall average antibody titre 6.27. The seroprevalences of six districts were found to be Chitwan (10\%), Sunsari (6\%), Kathmandu (2\%), Banke (8\%), Bhaktapur (2\%) and Jhapa (4\%) with their mean antibody titres in log form were found to be 6.8, 6.3, 5, 6, 6 and 6.5 respectively. These samples when categorised into three divisions of influenza risk areas viz. Buffer zone, Border market area and Outbreak area, the seroprevalence were found to be $8 \%, 6 \%$ and $2 \%$ and their mean antibody titre in $\log _{2}$ form were found to be 6.6, 6.3 and 5.5 respectively. The statistical analyses revealed that there is significant difference $(P<0.05)$ in age wise prevalence on group above 6 months and below 6 months. However, no significant difference ( $p>0.05)$ occurred in prevalence by district, sex and influenza risk area.
\end{abstract}

Keywords: LPAI, HI, Seroprevalence, titre, chi-square 


\section{INTRODUCTION}

Avian influenza subtype $\mathrm{H} 9$ that has been identified only in low pathogenic form (LPAI) should not be neglected by what the name suggests. This is so because H9 subtype infection is usually asymptomatic, but it is highly associated with virus shedding as it transmits easily from migratory bird to backyard poultry (e.g.: duck), from it to caged poultry population and even poultry to human population. Nepal is highly vulnerable to LPAI infection by migratory birds, from China (Tibet as well as North China) and Siberia (Russia), millions of them flying South West and South across the entire spread of the Northern boundaries, covering thickly populated areas beneath (both human and poultry: fowl as well as duck) (FAO and OIE 2009). The H9 subtype such as H9N2 virus strain is likely to get reassortment with other subtypes of Avian influenza i.e. can mutate to Highly Pathogenic Avian Influenzas (HPAI). The antigenic shift may result from mutation which is the genetic reassortment and adaptation of influenza viruses from one species to another. Antigenic shift results in new influenza A subtype (WHO, 2006) This causes high mortality in poultry population causing huge economic losses as well as grave public health hazards.

\section{MATERIALS AND METHOD}

The present study was conducted from August-2013 to March-2014. The potential site for avian influenza risk areas such as near migratory bird habitat in buffer region, outbreak areas and important poultry market areas of Nepal were selected. The selected district includes Chitwan, Sunsari, Jhapa, Kathmandu, Bhaktapur and Banke district. Altogether 300 blood samples were collected by using purposive sampling method and carried in icebox maintaining $4^{\circ} \mathrm{C}$ temperature and serum was separated later. All the samples were analyzed in virology laboratory, Animal Health Research Division, NARC, Khumaltar.

The serum samples were processed for Hemagglutination Inhibition (HI) test under OIE Manual of diagnostic Tests and Vaccines for Terrestrial Animals, 2014 and the standard Antigen and Antisera was bought from Charles River (USA). The HI titre is the highest dilution of serum causing complete inhibition of 4 HAU of antigen. The agglutination was assessed by tilting the plates. Only those wells in which the RBCs stream at the same rate as the control wells was considered to show inhibition.

\section{RESULT AND DISCUSSION}

The serovalence of serum samples of duck with HI positive (at $>3^{\text {rd }}$ well) at two-fold dilution revealed 5\% Seroprevalence of LPAI H9 and overall average antibody titre as 6.27. The seroprevalence on risk areas categories Buffer zone, Border market 
area and Outbreak area, were found to be highest in buffer zone (8\%) and lowest in outbreak area $(6 \%)$, antibody titre higher from buffer zone area. On district wise prevalence, Chitwan, Sunsari and Banke has higher prevalence than compared to Kathmandu, Bhaktapur and Jhapa, antibody titre being highest in Chitwan and lowest in Bhaktapur district. Age wise prevalence was found to be higher in age above 6 months $(7.78 \%$, antibody titre $=6.53)$ than age below 6 months $(2.25 \%$, Antibody titre $=5.33)$ while Sex wise prevalence was found to higher in female $(6.53 \%)$ than male $(4.80 \%)$. The seroprevalence and antibody titre on different research category is as shown in table 1 and 2.

Table 1: Statistical analysis on Seroprevalence

\begin{tabular}{|c|c|c|c|c|c|c|}
\hline S.N. & Category & Groups & $\begin{array}{c}\text { Positive } \\
\text { samples (\%) }\end{array}$ & $\begin{array}{c}\text { Total } \\
\text { Samples }\end{array}$ & $\begin{array}{l}\text { Probability } \\
\text { (P) }\end{array}$ & $\chi^{2}$ value \\
\hline & \multirow{6}{*}{ District } & Chitwan & $5(10)^{\mathrm{a}}$ & 50 & & \\
\hline & & Sunsari & $3(6)^{a}$ & 50 & & \\
\hline \multirow[t]{4}{*}{1} & & Kathmandu & $1(2)^{a}$ & 50 & N.S & 5.282 \\
\hline & & Banke & $4(8)^{\mathrm{a}}$ & 50 & & \\
\hline & & Jhapa & $2(4)^{a}$ & 50 & & \\
\hline & & Bhaktapur & $1(2)^{a}$ & 50 & & \\
\hline \multirow[t]{2}{*}{2} & $\begin{array}{l}\text { Risk } \\
\text { areas }\end{array}$ & $\begin{array}{l}\text { Buffer zone } \\
\text { Outbreak area }\end{array}$ & $\begin{array}{l}8(8)^{\mathrm{a}} \\
6(2)^{\mathrm{a}}\end{array}$ & $\begin{array}{l}100 \\
100\end{array}$ & N.S & 8.997 \\
\hline & & Market area & $2(6)^{a}$ & 100 & & \\
\hline \multirow[t]{2}{*}{3} & Age & Below 6 months & $3(2.25)$ & 130 & $*$ & $4 . .82$ \\
\hline & & $\begin{array}{l}\text { Above } \\
6 \text { month }\end{array}$ & $13(7.78)$ & 154 & & \\
\hline \multirow[t]{2}{*}{4.} & Sex & Male & $10^{\mathrm{a}}$ & 198 & N.S & .542 \\
\hline & & Female & $6^{\mathrm{a}}$ & 86 & & \\
\hline
\end{tabular}

a,b Indicate significant differences $(\mathrm{P}<0.05)$ between the means of the groups, NS = not significant $(\mathrm{P}>0.05)$ 
Table 2: Statistical analysis on antibody titre

\begin{tabular}{|c|c|c|c|c|c|c|}
\hline S.N. & Category & Groups & $\begin{array}{l}\text { Positive } \\
\text { samples }\end{array}$ & Titre & Probability $(\mathrm{P})$ & $\chi^{2}$ value \\
\hline & \multirow{6}{*}{ District } & Chitwan & 5 & 6.8 & & \\
\hline & & Sunsari & 3 & 6.3 & N.S & \\
\hline \multirow[t]{4}{*}{1} & & Kathmandu & 1 & 5 & & 18.415 \\
\hline & & Banke & 4 & 6 & & \\
\hline & & Jhapa & 2 & 6.5 & & \\
\hline & & Bhaktapur & 1 & 6 & & \\
\hline \multirow[t]{2}{*}{2} & Risk areas & $\begin{array}{l}\text { Buffer zone } \\
\text { Outbreak area }\end{array}$ & $\begin{array}{l}8 \\
6\end{array}$ & $\begin{array}{l}6.6 \\
5.5\end{array}$ & N.S & 8.997 \\
\hline & & Market area & 2 & 6.3 & & \\
\hline \multirow[t]{2}{*}{3} & Age & Below 6months & 3 & 5.33 & N.S & 8.056 \\
\hline & & Above 6 month & 13 & 6.53 & & \\
\hline \multirow[t]{2}{*}{4.} & Sex & Male & 10 & 6.3 & N.S & \\
\hline & & Female & 6 & 6.4 & & 7.557 \\
\hline
\end{tabular}

a,b Indicate significant differences $(\mathrm{P}<0.05)$ between the means of the groups, NS = not significant $(\mathrm{P}>0.05)$

There was no significance difference $(\mathrm{P}>0.05)$ between antibody titre of different districts, risk areas, age and sex categories. The seroprevalence in this study was low as compared to seroprevalence study conducted at Iran which was $72.98 \%$ for LPAI H9N2 (Hadipour, 2011). The possible reason for such a low prevalence in duck is that the density of duck population and the market access of live duck is low. So, the spread of this virus is still limited in it.

Higher sero-prevalence in Chitwan district might be due to migratory bird habitat and the probable interaction and contamination of secretions of migratory birds with free ranging ducks. The absence of clinical signs of influenza in ducks despite high antibody titers in our study in samples from buffer zone area could be due to persistent exposure and acquired resistance of these birds to influenza virus in the environment. It supports the finding of Hadipour (2011) who found high antibody titers among chickens with no clinical symptoms observed. 
Sero-prevalence in Banke district and Kathmandu district in our study was found to be $8 \%$ and $2 \%$ respectively. However, on a surveillance study of Avian influenza on 2005- 2006 by Panta et al., 2007, none of the duck sample were found positive in Kathmandu ( $\mathrm{n}=11)$ and Banke district $(\mathrm{n}=4)$. Interestingly, the seroprevalence of Avian influenza subtype $\mathrm{H} 9$ on two different age group describes that both young group and adult age group has antibody for $\mathrm{H} 9$ and the adult group having higher mean antibody titre in $\log _{2}$ form as 6.33 . High antibody titre in adult age could be correlated to frequency of exposure. Higher exposure causes subsequent increase in antibody titre.

The sero-prevalence of $\mathrm{H} 9$ on adult age group is higher than young age group. This finding is similar to that of Karki et al., (2014) who found that older ducks had higher proportion of Influenza A seropositive in ducks from Kathmandu district (Karki et al., 2014). This might be linked to the foraging behaviour as the range of foraging in adult is wider as well as longer time for exposure. Also, higher mean antibody titre in $\log _{2}$ form as 6.33 was found in adult age group. High antibody titre in adult age could be correlated to frequency of exposure. Higher exposure might have caused subsequent increase in antibody titre. The seroprevalence of Outbreak area on our study was found to be lowest (2\%) than samples taken from buffer region area and Market area. In study done by Hymann (2012), none of the sample was positive for $\mathrm{H} 9$ but found seroprevalence for $\mathrm{H} 5$ and $\mathrm{H} 7$ from samples taken from H5N1 outbreak area in Cote d'Ivoire.

\section{CONCLUSION}

No significant difference occurred between prevalence of samples taken from buffer zone, market area and outbreak area. However, the high antibody titer and prevalence rate on buffer zone explains that this area would be high-risk area for virus transmission and mutation of LPAI leading to HPAI outbreak. Chitwan district and Sunsari has high prevalence of LPAI as compared to other districts. The scavenging ducks with high antibody titre is likely to transmit $\mathrm{H} 9$ virus to the farmer or nearby poultry farm. Hence, requiring surveillance of AI on this district needs to be highly prioritized. The age group above 6 months has high probability of transmitting infection than compared to age below 6 months requiring need for sero monitoring of this age group. Finally, surveillance (epidemiological, laboratory), supervision, monitoring and quarantine activities should be furthermore strengthened. Workers involved in the surveillance and transporting poultry and duck flocks must be protected with proper clothing and standard procedure for disposal of suspected poultry and its products should be developed and implemented. 


\section{REFERENCES}

Aamir, U.B., U. Wernery, N. Ilyushina and R.G. Webster. 2007. Characterization of avian H9N2 influenza viruses from United Arab Emirates 2000 to 2003. Virol 361: 45-55.

Acharya, S., M.P Acharya and T. Khanal. 2012. Sero-Surveillance of Avian Influenza Subtype H9N2 on live bird market of Kathmandu Valley. Souvenir 2012. NVA. P37 Available at: http://www.nva.org.np/files/publication/Souvenir.pdf (Retrieved on Jan 4, 2013).

FAO and OIE. 2009. Situation of HPAI in Nepal. AICP, Kathmandu, Nepal.

Hadipour M. 2010. Seroprevalence survey of $\mathrm{H}_{9} \mathrm{~N}_{2}$ avian influenza virus in backyard chickens around the Caspian Sea in Iran. Vet journal. 20p.

Hadipour, M. 2010. Prevalence of antibodiesto H9N2 Avian Influenza virus in Backyard Chickens around the Maharlou Lake in Iran. Pakistan Veterinary Journal. 2p.

Hymann, E., A. Kouakou, A. Koassi, Y. Koffi. 2012. Surveillance for avian influenza in poultry and science, West Africa, 2006-2008.

Karki, S., Lupiani, B., Budke, C.M., Manandhar, S. and Ivanek, R., 2014. CrossSectional Serosurvey of Avian Influenza Antibodies Presence in Domestic Ducks of Kathmandu, Nepal. Zoonoses and public health, 61(6), pp.442-448.

Office International Des Epizootic. 2009. Country Affected Areas (H5N1) in 2009. Date/Place of Latest Outbreak Affected Populations. (19-10-2009). Available at: Http://www.oie.org/AI html. 2009 (Retrieved on Jan 2, 2013).

OIE. 2014. Avian Influenza. OIE terrestrial manual 2014. Available at: http://oie.org/ manual.html. (Retrieved on Jan 8, 2014).

Pant, G., W. Sellar and T. Paul. 2006. Surveillance of Influenza in Nepal. 2004-2005. Avian Disease. Vol 51. Available from: http://www.jstor. org/ er/ $10.2307 / 4493224$ ?uid $=2129 \&$ uid $=2 \&$ uid $=70 \&$ uid $=4 \&$ sid $=21104242408467$ (Retrieved from Jan 13, 2013).

WHO 2006. World Health Organization. Influenza research at the human and animal interface. Report of a WHO working group. WHO: Geneva, Switzerland? Available from: http://www.who.int/ csr/resources/ publications /influenza/ WHO, CDS, EPR_GIP_2006_3C. (Retrieved on Feb 2, 2013). 